\title{
Biomagnification of mercury in trophic relation of Great Cormorant (Phalacrocorax carbo) and fish in the Vistula Lagoon, Poland
}

\author{
Małgorzata Misztal-Szkudlińska • Piotr Szefer • \\ Piotr Konieczka • Jacek Namieśnik
}

Received: 8 February 2010 / Accepted: 17 June 2010 / Published online: 13 July 2010

(C) The Author(s) 2010. This article is published with open access at Springerlink.com

\begin{abstract}
Total mercury $(\mathrm{Hg})$ concentrations were determined by CV-AAS in selected tissues (liver, kidney, and muscle) of the Great Cormorant and some fish species (herring, ruffe, European smelt, tench, roach, Crucian carp, and Prussian carp) from the Vistula Lagoon ecosystem (Poland). Significant correlations between $\mathrm{Hg}$ concentrations in the kidneys and muscle of cormorants ( $U$ test, $p<0.05$ ) were found; levels of the metal were highest in the birds' liver and kidneys. Total $\mathrm{Hg}$ concentrations in the fish decreased in the following order: roach $>$ Prussian carp $>$ Crucian carp $>$ tench $>$ European smelt $>$ ruffe $>$ herring. The biomagnification factor of $\mathrm{Hg}$ for the cormorant relative to the fish decreased in the following sequence: herring $>$ ruffe $>$ European smelt $>$ tench $>$ Crucian carp $>$ roach $=$ Prussian carp. It was significantly greater than unity, especially for the cormorant-herring trophic relationship. This implies that $\mathrm{Hg}$ is
\end{abstract}

M. Misztal-Szkudlińska · P. Szefer $(\varangle)$

Department of Food Sciences, Medical University

of Gdansk, al. Gen. J. Hallera 107,

80-416, Gdansk, Poland

e-mail: pszef@gumed.edu.pl

P. Konieczka · J. Namieśnik

Department of Analytical Chemistry, Chemical

Faculty, Gdansk University of Technology,

ul. Narutowicza 11/12, 80-233, Gdansk, Poland biomagnified in the cormorant in relation to its prey.

Keywords Total mercury - Great Cormorant • Fish $\cdot$ Biomagnifications $\cdot \mathrm{CV}$-AAS

\section{Introduction}

In the natural environment, mercury $(\mathrm{Hg})$ is derived from both anthropogenic activities and natural sources. Up to now, anthropogenic emissions of $\mathrm{Hg}$ to the environment have been increasing substantially relative to natural emissions. The most important sources of $\mathrm{Hg}$ pollution in aquatic systems are atmospheric deposition, erosion, urban discharges, agricultural materials, mining, combustion, and industrial effluents (Wang et al. 2004). Most $\mathrm{Hg}$ pollution resides in the aquatic environment, resulting in its rapid incorporation into the food chain and biomagnification in organisms.

As chemical elements are transported along the successive levels of the food chain, their concentrations may rise at each higher trophic level, an effect known as biomagnification (Gray 2002). One of the properties of $\mathrm{Hg}$ is its ability to bioaccumulate in soil, plants, animals, and humans. The harmfulness of this metal depends on the time of exposure to it and its speciation; $\mathrm{Hg}$ vapors entering organisms through their respiratory systems 
are especially dangerous. Other chemical forms of $\mathrm{Hg}$ can also be ingested with food. Absorbed $\mathrm{Hg}$ circulates with the blood and accumulates in some tissues. Higher levels were recorded in the critical organs (kidney, liver) and muscle. Fisheating birds, like Great Cormorant, are exposed to $\mathrm{Hg}$ biomagnification mostly because of their location at the end of the food chain (Houserová et al. 2007; Saeki et al. 2000). The toxic effects of $\mathrm{Hg}$ in birds include reduced food intake leading to weight loss, progressive weakness in the wings and legs leading to difficulty in flying, walking, and standing, and an inability to coordinate muscle movements (Kim et al. 1996; Scheuhammer and Graham 1999). High concentrations of $\mathrm{Hg}$ in birds most often affect their immune, detoxification, and nervous systems, and cause reproductive impairment (Boening 2000; Houserová et al. 2007).

The aims of this study were to assess the intertissue distribution of $\mathrm{Hg}$ in the Great Cormorant (Phalacrocorax carbo) and to estimate the extent to which this metal is biomagnified in relation to the bird's food, i.e., fish.

\section{Materials and methods}

\section{Study area}

The Vistula Lagoon is a semienclosed, shallow, coastal basin separated from the Gulf of Gdansk by the Vistula Spit and connected with the Baltic Sea via the Baltijsk Strait. The lagoon is $90.7 \mathrm{~km}$ long (35.1 km in the Polish Sector), has an average depth of $3.1 \mathrm{~m}$, and has a maximum depth of $5.2 \mathrm{~m}$; the depth of the dredged ship channel in the north-eastern part of the lagoon is $11 \mathrm{~m}$. The area of the lagoon is $861 \mathrm{~km}^{2}, 473 \mathrm{~km}^{2}$ of which lie within the borders of the Russian Federation and $388 \mathrm{~km}^{2}$ in Poland. The Vistula Lagoon consists of shallow, brackish water with a salinity between 0.1 and 10 psu (average, 4-5.5 psu). The hydrological status of the lagoon is defined chiefly by the inflow of fresh water from 20 rivers and water exchange with the Baltic Sea. The main inflow is supplied by the Russian River Pregola; the inflow from Polish rivers comes from the Bauda, Elblag, Pasłęka, Nogat, and Szkarpawa (Ezhova et al. 2005; Uścinowicz and Zachowicz 1996).
The Vistula Lagoon is polluted by nutrients, mostly the residues of various plant-protection products and fertilizers used in agriculture. Sewages from the mechanical-biological wastewater treatment plants at Tolkmicko, Frombork, Krynica Morska, and Piaski enter the lagoon on a continuous basis. All this raises the fertility of the lagoon-eutrophication is thus an ongoing process. Since 1950, eutrophication has increased dramatically; the fertility of the Lagoon was recently assessed as being four to five times greater than that of the Baltic Sea itself (Szefer 2002). The Vistula Lagoon has, therefore, been included in the natural environment protection program Natura 2000 and put on the list of Baltic Sea Protected Areas introduced by HELCOM (Szefer 2002).

\section{Great Cormorant and fish}

The largest European colony of Great Cormorants is located at Katy Rybackie near the Vistula Lagoon. The number of individuals in the population rose continuously until 2004, when a total of 11,500 pairs occupied the colony; currently, the population is in regression, possibly because of aging. Great Cormorants play an important role in freshwater ecosystems like the Vistula Lagoon because they are numerous and widespread top predators and they influence the structure and dynamics of fish communities (Stempniewicz et al. 2003).

Great Cormorants are a relatively large birds, weighing from 1.3 to $3.1 \mathrm{~kg}$ and with a wingspan from 1.3 to $1.6 \mathrm{~m}$. There is hardly any sexual dimorphism: females are slightly smaller and lighter than males. The feathers of mature birds are black with white spots on the cheeks and thighs. Immature individuals are recognized by the white belly with various numbers of dark spots (Baker 1993; Goc 2004; Przybysz 1997). Normally, three to six eggs are laid by the female at 2- to 3-day intervals. The incubation period is about 3 weeks (from 23 to 31 days). Incubation as well as care of the chicks is shared between males and females. The usual level of breeding success is two to three chicks per pair.

Great Cormorants are fish-eating birds without any particular preferences in their prey species, 
mostly choosing the easiest and most numerous to catch (Goc 2004; Przybysz 1997). They hunt individually or in flocks (Przybysz 1997). Their staple diet consists mostly of fish from the families Cyprinidae and Percidae (Stempniewicz and Grochowski 1997): ruffe (Gymnocephalus cernuus), perch (Perca fluviatilis) and roach (Rutilus rutilus), and more rarely tench (Tinca tinca) and Prussian carp (Carassius gibelio); in addition, fair numbers of fish from other families are taken, like European smelt (Osmerus eperlanus) and herring (Clupea harengus) (Martyniak et al. 2003; Stempniewicz and Grochowski 1997; Stempniewicz et al. 2003). Analysis of Great Cormorants' pellets in the colony (1996) showed that ruffe was the main component of the birds' diet. The percentage composition of the cormorants' diet (Fig. 1) is as follows: ruffe, 74.6\%; European smelt, $11.6 \%$; perch, $6 \%$; roach, $3.7 \%$; herring, 1.2\%; other species, $<1 \%$ (Martyniak et al. 2003). Great Cormorants eat fish species of little industrial importance: the basic item from the Vistula Lagoon area is the ruffe, known as "fish weed" by fishermen.

Herring is a commercially very important marine species that occurs in the Vistula Lagoon seasonally, mainly in spring during its spawning season. The juveniles are zooplanktivorous. Roach is a common, freshwater species in the Vistula Lagoon, foraging mainly on benthic organisms like mollusks; its spawning period is from May to June. Tench is common close to rivers; it inhabits the littoral zone and feeds on benthic organisms. Crucian carp and Prussian carp are benthivorous, medium-sized fish common in the Vistula Lagoon where they inhabit the littoral zone. European smelt is also a common species, feeding mainly on zooplankton, including fish larvae. Ruffe is a common benthivorous species of no commercial importance (Brylińska 1991; Psuty 2010).

The cormorants from Katy Rybackie colony make foraging trips to the Vistula Lagoon, to the Gulf of Gdańsk as well as to the mouth of the River Vistula. The availability of fish varies seasonally. The Vistula Lagoon is the main feeding area following the birds' return from their wintering grounds-from February to the beginning of April. During this time, cormorants catch small percid and cyprinid fish, like ruffe, roach, and bream (Bzoma et al. 2003). At the beginning of the breeding season, herring become the major part of the birds' diet because these fish become easy to catch during their spawning season (Kanarek and Rolbiecki 2006). Later, as the breeding season progresses, the other areas (Gulf of Gdańsk) increase in importance. This is probably due to the colony's greater food requirements when fish resources in the Vistula Lagoon are shrinking (Bzoma et al. 2003; Goc et al. 2003; Stempniewicz et al. 2003).

Sampling and analytical method

The Great Cormorants were shot by hunters (by permission of the local environment protection authorities) in the Polish Sector of the Vistula Lagoon during June 2006. The birds were identified as $P$. carbo using the method suggested by Baker (1993). Fifty-five specimens were obtained and then sorted by sex (24 females, 31 males) and age (44 adults, 11 immatures). They were
Fig. 1 Percentage composition of the diet of Great Cormorant $(P$. carbo) in the Vistula Lagoon ecosystem in 1996 (from Martyniak et al. 2003)

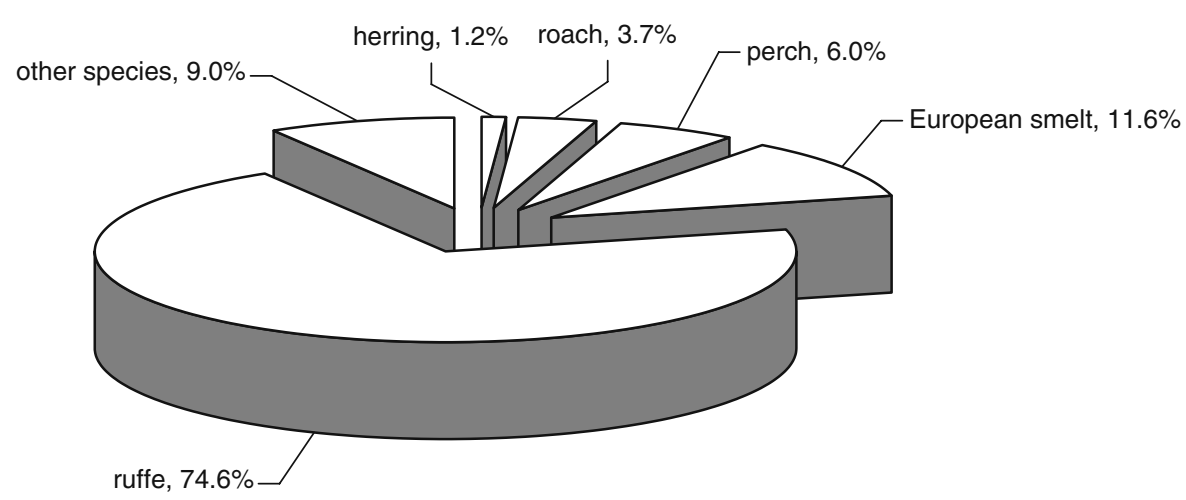


dissected in order to separate tissues and organs: kidneys, liver, muscles, oesophagus, stomach, intestines, trachea, lungs, skin, cardiac muscle, and feathers. The separate tissues and organs of the birds and whole specimens of fish were immediately deep-frozen, freeze-dried (lyophilized), and homogenized. The total $\mathrm{Hg}$ concentration was determined in the fish constituting the cormorant's diet in order to discover the extent to which the $\mathrm{Hg}$ load from the fish is passed on to the birds. The following species of fish were caught by fyke net in the north-western Vistula Lagoon near the cormorant colony at Katy Rybackie in June 2006: herring, tench, roach, European smelt, ruffe, Crucian carp (Carassius carassius) and Prussian carp. The fish species were identified using Brylińska's method (1991).

Whole specimens of fish and individual cormorant tissues and organs were analyzed. The tissues and organs were lyophilized, homogenized, and weighed (from $10 \pm 0.1$ to $50 \pm 0.1 \mathrm{mg}$ ), placed in precleaned combustion boats, and automatically inserted into the Mercury/MA-2000 analyzer system (NIC-Japan). Samples were thermally decomposed at $800^{\circ} \mathrm{C}$ under clean air flow. The total $\mathrm{Hg}$ concentration was determined by CV-AAS at $253.65 \mathrm{~nm}$. Three analytical subsamples were prepared from each sample. Quality control was assured by analyses of certified reference materials: DORM-2 (National Research Council, Canada), BCR-463, and ERM-CE278 (IRMM, Belgium). The respective recoveries (a measure of accuracy) of total $\mathrm{Hg}$ were $101.0 \%$, $97.1 \%$, and $98.6 \%$, and the respective standard deviations ( $\mathrm{SD}$; a measure of precision) were $0.09,0.09$, and $0.10 \%$. The limit of detection was $0.12 \mathrm{ng}$. The estimated variability of $\mathrm{Hg}$ concentrations in three subsamples of particular tissues was satisfactory, since the coefficients of variation $(\mathrm{CVs})$ were $0.49-6.65 \%, 0.12-11.18 \%, 0.30$ $4.68 \%$, and $0.89-14.4 \%$ for kidney, liver, muscle, and feathers, respectively. Since CVs were generally $<10 \%$, it was possible to use $<50 \mathrm{mg}$ samples.

\section{Statistical analysis}

The concentration data were processed statistically using STATISTICA 8.0 for Windows (Copyright $^{\circledR}$ StatSoft, Inc. 1984-2007). Cluster analysis was used to compare the $\mathrm{Hg}$ content in particular tissues in order to estimate the total pool of $\mathrm{Hg}$ in the whole bird body. To check whether there was any statistically significant difference in $\mathrm{Hg}$ concentrations between sex and age, the data were processed using the nonparametric Mann-Whitney $U$ test $(p<0.05)$.

To estimate the total $\mathrm{Hg}$ content in birds and to calculate the biomagnification factor (BMF), $\mathrm{Hg}$ concentrations in cormorants and fish were recalculated from dry weight (d.w.) to wet weight (w.w.).

Estimation of the total $\mathrm{Hg}$ content in birds

Required data:

- wet mass of the whole bird body [in grams]

- wet mass of all the separate tissues, especially liver, kidney and muscle [in grams]

- $\mathrm{Hg}$ concentration in liver [in micrograms per gram w.w.]

- Hg concentration in kidney [in micrograms per gram w.w.]

- Hg concentration in all the tissues analyzed [in micrograms per gram w.w.]

The principal assumptions:

- the muscles are the main part (in terms of weight) of a bird's body

- the $\mathrm{Hg}$ concentration (in micrograms per gram w.w.) in all the tissues except kidney and liver is similar to that in the muscles. This assumption is supported by cluster analysis data (Fig. 2): cluster analysis shows that the concentration of $\mathrm{Hg}$ in muscles is similar to that in the other tissues, except kidney, liver, and feathers. $\mathrm{Hg}$ concentrations in bird tissues other than those analyzed in the present study may be omitted from the calculation of both total $\mathrm{Hg}$ content and BMF because their mass contribution to the whole body of the cormorant is insignificant. For instance, the mass contribution of bones to the whole body estimated in our study was $\sim 7 \%$ and the content of $\mathrm{Hg}$ in bones reported by $\mathrm{Nam}$ et al. (2005) was $\sim 1-2 \%$ of its total pool in the whole bird's body. 
Fig. 2 Cluster analysis data concerning the intertissue distribution of $\mathrm{Hg}$ (in micrograms per gram w.w.) in Great Cormorants (P. carbo) from the Vistula Lagoon. This shows that the $\mathrm{Hg}$ concentration in muscle tissue is similar to that in six other tissues, except kidney, liver, and feathers

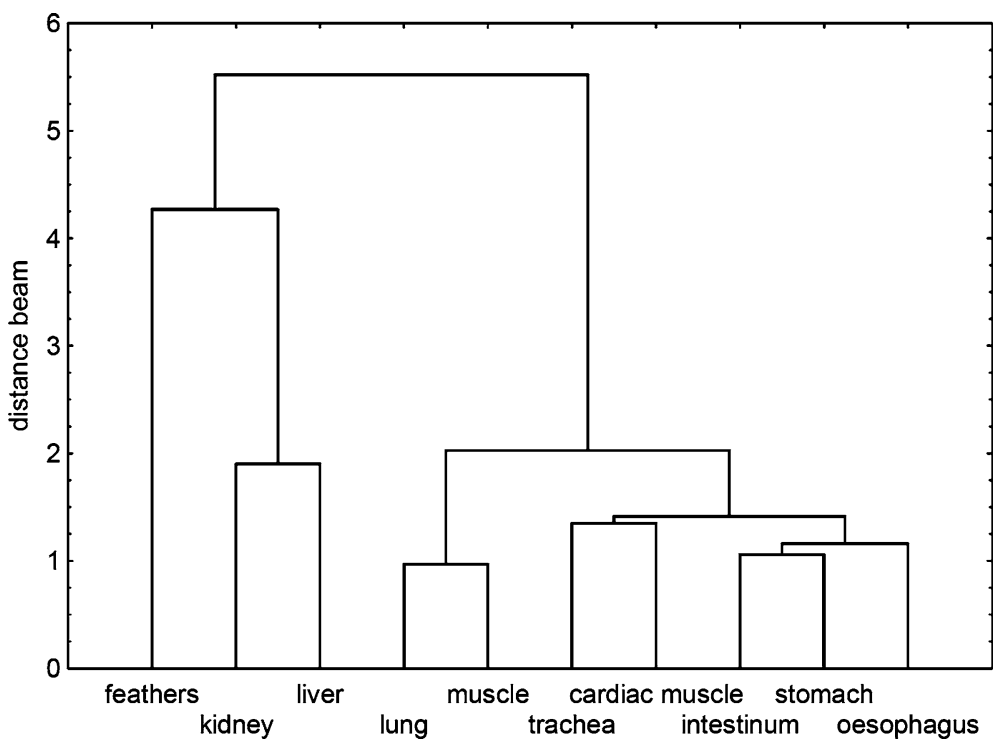

Total $\mathrm{Hg}$ can be then calculated as the sum of the total $\mathrm{Hg}$ in kidney, liver, feathers, and the rest of the body. As the weights of kidney, liver, and feathers and also the $\mathrm{Hg}$ concentration in these tissues are known, the total amount of $\mathrm{Hg}$ in kidney, liver, and feathers is:

$$
\begin{aligned}
& M_{\text {Hg kidney }}=M_{\text {kidney }} \times C_{\text {kidney }} \\
& M_{\text {Hg liver }}=M_{\text {liver }} \times C_{\text {liver }} \\
& M_{\text {Hg feathers }}=M_{\text {feathers }} \times C_{\text {feathers }}
\end{aligned}
$$

where $M$ is the wet mass of kidney/liver/feathers [in grams], $M_{\mathrm{Hg}}$ is the total amount of $\mathrm{Hg}$ in kidney/liver/feathers [in micrograms], and $C$ is the concentration of $\mathrm{Hg}$ in kidney/liver/feathers [in micrograms per gram w.w.].

Assuming that the whole of the remainder of the bird's body has a $\mathrm{Hg}$ concentration similar to that in muscle tissue, the amount of $\mathrm{Hg}$ in the remainder can be calculated using the following formula:

$$
\begin{aligned}
M_{\text {Hg rest }}= & \left(M_{\text {whole body }}-M_{\text {kidney }}\right. \\
& \left.-M_{\text {liver }}-M_{\text {feathers }}\right) \times C_{\text {muscle }}
\end{aligned}
$$

where $M$ is the wet mass of kidney/liver/ feathers/whole body [in grams], $M_{\mathrm{Hg} \text { rest }}$ is the total amount of $\mathrm{Hg}$ in all tissues except kidney, liver and feathers [in micrograms], and $C$ is the concentration of $\mathrm{Hg}$ in muscle [in micrograms per gram w.w.].
The total amount of $\mathrm{Hg}$ in the whole bird's body can thus be calculated as follows:

$$
\begin{aligned}
M_{\mathrm{Hg} \text { total }}= & M_{\mathrm{Hg} \text { kidney }}+M_{\mathrm{Hg} \text { liver }} \\
& +M_{\mathrm{Hg} \text { feathers }}+M_{\mathrm{Hg} \text { rest }} .
\end{aligned}
$$

\section{Biomagnification factor}

Vistula Lagoon cormorants feed mainly on herring, tench, roach, European smelt, ruffe, Crucian carp, and Prussian carp (Martyniak et al. 2003). The BMF was calculated on the basis of the $\mathrm{Hg}$ concentrations in the liver, kidney, muscles, and total body (calculated as above) of cormorants. BMF is defined by Ciesielski et al. (2006):

$\mathrm{BMF}=C_{(\text {predator })} / C_{(\text {prey })}$

where $C_{\text {(predator) }}$ is the concentration of $\mathrm{Hg}$ (in micrograms per gram w.w.) in predator, $C_{(\text {prey })}$ is the concentration of $\mathrm{Hg}$ (in micrograms per gram w.w.) in prey.

\section{Results}

Total $\mathrm{Hg}$ concentrations in cormorant tissues decreased in the following order: kidney $>$ liver $>$ 
Fig. 3 Concentrations of total $\mathrm{Hg}$ (in micrograms per gram d.w.) in muscle tissue from male and female Great Cormorants (P. carbo) from the Vistula Lagoon

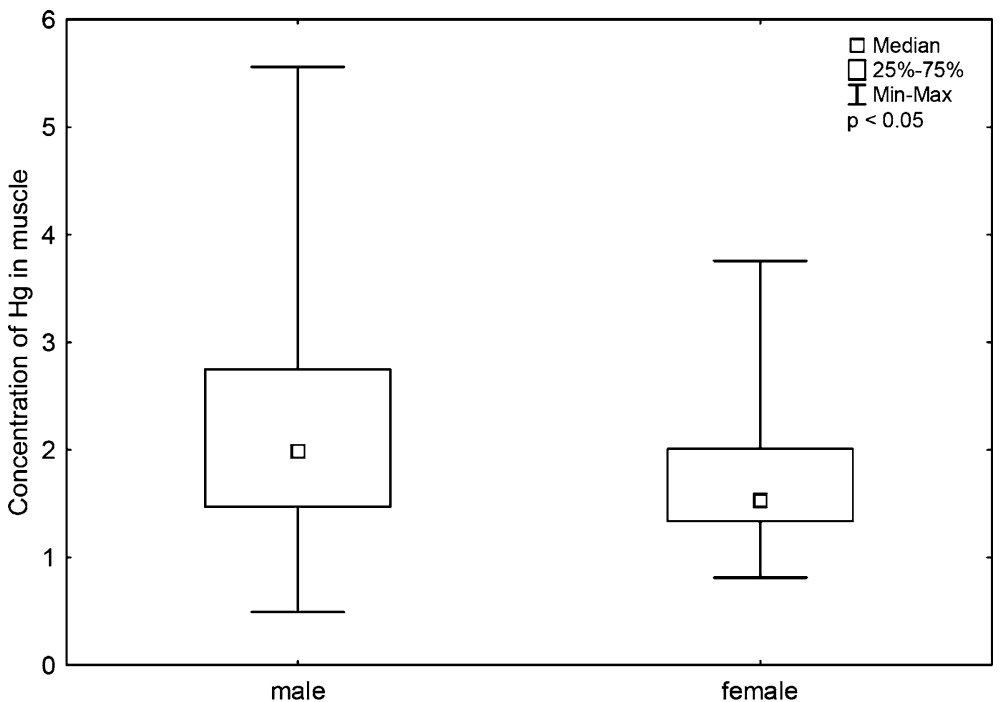

muscle. Concentrations of $\mathrm{Hg}$ in adults varied widely and were as follows: $30.21 \pm 47.93 \mu \mathrm{g} / \mathrm{g}$ d.w. in kidney, $15.51 \pm 17.30 \mu \mathrm{g} / \mathrm{g}$ d.w. in liver, and $2.15 \pm 1.10 \mu \mathrm{g} / \mathrm{g}$ d.w. in muscle. In the case of immature specimens, the respective values were $17.58 \pm 22.96,10.96 \pm 11.42$, and $1.61 \pm$ $0.82 \mu \mathrm{g} / \mathrm{g}$ d.w. There were statistically significant sex-dependent variations in muscle and kidney concentrations of $\mathrm{Hg}$ ( $U$ test, $p<0.05$; Figs. 3 and 4).
All the fish (omnivorous) analyzed constitute potential food for the cormorants in the Vistula Lagoon. High levels of total $\mathrm{Hg}$ were found in the whole bodies of roach and Prussian carp $(0.110 \pm 0.060 \mu \mathrm{g} / \mathrm{g}$ w.w. $)$; levels were lowest in herring $(0.008 \pm 0.003 \mu \mathrm{g} / \mathrm{g}$ w.w.). Figure 5 illustrates the variations in $\mathrm{Hg}$ concentration, which decreased in the following sequence: roach $=$ Prussian carp $>$ Crucian carp $>$ tench $>$ European smelt $>$ ruffe $>$ herring.
Fig. 4 Concentrations of total $\mathrm{Hg}$ (in micrograms per gram d.w.) in kidney tissue from male and female Great Cormorants (P. carbo) from the Vistula Lagoon

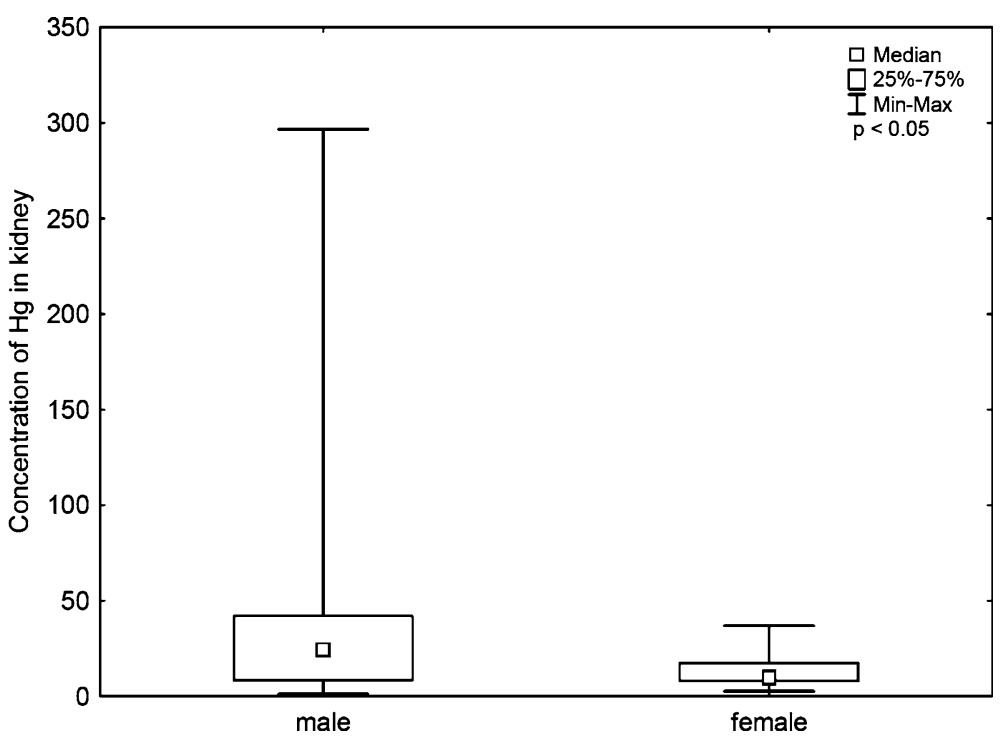


Fig. 5 Concentration of total $\mathrm{Hg}$ (in micrograms per gram w.w.) in the whole body of fish from the Vistula Lagoon

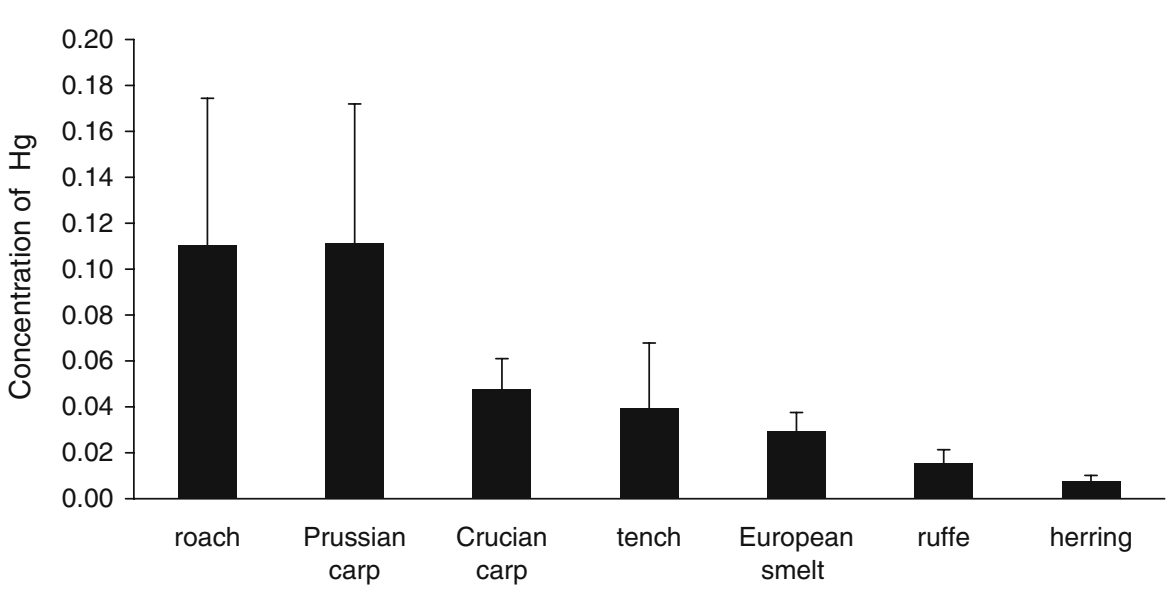

\section{Discussion}

Large $\mathrm{Hg}$ concentrations in liver and kidney, as opposed to other tissues, have been reported in fish-eating birds such as cormorants, eiders, guillemots, and gulls (Boening 2000; Houserová et al. 2007; Nam et al. 2005; Saeki et al. 2000). Total $\mathrm{Hg}$ concentrations decreased in the following order: liver $>$ kidney $>$ muscle (Houserová et al. 2007; Nam et al. 2005; Saeki et al. 2000). The data obtained in the present study are compared with those reported elsewhere (Table 1). Our study, however, indicates $\mathrm{Hg}$ levels were higher in kidney than in liver tissue. This discrepancy may be due to the different numbers of cormorants used in the investigations carried out by various authors. Houserová et al. (2005, 2007) noted that liver $\mathrm{Hg}$ concentrations were higher in adult cormorants than in immature individuals from the Záhlinice ecosystem (Czech Republic). Much higher mean renal $\mathrm{Hg}$ concentrations were found in both adults and immatures among the Vistula Lagoon cormorants than those reported in the available literature (Houserová et al. 2007; Nam et al. 2005; Saeki et al. 2000). Muscle concentrations, however, were similar to those (1.1$3.4 \mu \mathrm{g} / \mathrm{g}$ ) reported elsewhere (Houserová et al. 2007; Nam et al. 2005).

$\mathrm{Hg}$ concentrations in different species of the genus Phalacrocorax vary, sometimes very significantly. Honda et al. (1990) analyzed two specimens of Japanese Cormorant (Phalacrocorax capillatus) from the North Pacific Ocean and obtained the following results: $1.03 \mu \mathrm{g} / \mathrm{g} \mathrm{d}$.w. for muscle, $4.00 \mu \mathrm{g} / \mathrm{g} \mathrm{d}$.w. for liver, and $2,33 \mu \mathrm{g} / \mathrm{g}$ d.w. for kidney. According to Henny et al. (2002), Double-crested Cormorant (Phalacrocorax auritus) from the Carson River ecosystem in Nevada concentrated 134.80 and $69.36 \mu \mathrm{g} \mathrm{Hg} / \mathrm{g}$ w.w. in liver and kidney, respectively. Liver, muscle, and feathers were analyzed for total $\mathrm{Hg}$ concentration in $P$. auritus nestlings from two reservoirs in south-central New Mexico (Caldwell et al. 1999). In Elephant Butte Reservoir, the $\mathrm{Hg}$ concentrations in liver, muscle, primary feathers, secondary feathers, and tail feathers were $0.40,0.17$, $2.42,2.06$, and $2.34 \mu \mathrm{g} / \mathrm{g}$ w.w., respectively. However, generally higher levels were observed in the Caballo Reservoir in primary feathers $(3.54 \mu \mathrm{g} / \mathrm{g}$ w.w.), secondary feathers $(4.89 \mu \mathrm{g} / \mathrm{g}$ w.w. $)$, and tail feathers (4.01 $\mu \mathrm{g} / \mathrm{g}$ w.w.; Caldwell et al. 1999). The mean concentration of $\mathrm{Hg}$ in the feathers of six specimens of Cape Cormorant (Phalacrocorax capensis) from Namibia in southern Africa amounted to $251 \mathrm{ng} / \mathrm{g}$ d.w. (Burger and Gochfeld 2001).

The wide range of values obtained in our studies may be the result of the cormorants' being exposed to pollution for different lengths of time. The individual birds were placed in two age classes: adults older than 2 years and sexually immature specimens younger than 2 years. This means that, within the adult group, there were specimens belonging to the third year, fourth year, 
Table 1 Comparison of mean concentrations of $\mathrm{Hg}$ (in micrograms per gram d.w.) in the liver, kidney, and muscle of Great Cormorant (P. carbo) in different areas

\begin{tabular}{|c|c|c|c|c|c|}
\hline Tissue & $\mathrm{Hg}$ & $\mathrm{SD}$ & Range & Number & Location \\
\hline Adult/immature/pull & & & & 9 & Tokyo, Japan (Saeki et al. 2000) \\
\hline Liver & 1.2 & 0.5 & $0.6-2.0$ & & \\
\hline Kidney & 0.9 & 0.7 & $0.2-2.5$ & & \\
\hline Muscle & 0.3 & 0.2 & $0.2-0.6$ & & \\
\hline Adult/immature/pull & & & & 10 & Lake Biwa, Japan (Saeki et al. 2000) \\
\hline Liver & 1.7 & 0.8 & $0.7-3.5$ & & \\
\hline Kidney & 1.5 & 1.0 & $0.5-3.7$ & & \\
\hline Muscle & 0.5 & 0.2 & $0.2-1.1$ & & \\
\hline Adult & & & & 8 & Záhlinice, Czech Republic (Houserová et al. 2007) \\
\hline Liver & 42.2 & 6.28 & - & & \\
\hline Kidney & 7.2 & 1.0 & & & \\
\hline Muscle & 3.4 & 0.37 & & & \\
\hline Immature & & & & 8 & Záhlinice, Czech Republic (Houserová et al. 2007) \\
\hline Liver & 7.5 & 1.63 & - & & \\
\hline Kidney & 4.1 & 0.49 & & & \\
\hline Muscle & 2.5 & 0.33 & & & \\
\hline Adult & & & & 4 & Japan (Nam et al. 2005) \\
\hline Liver & 12 & 9 & - & & \\
\hline Kidney & 14 & 9 & & & \\
\hline Muscle & 1.1 & 0.3 & & & \\
\hline Adult & & & & 44 & Vistula Lagoon, Poland, This study \\
\hline Liver & 15.51 & 17.30 & $1.99-80.7$ & & \\
\hline Kidney & 30.21 & 47.93 & $1.56-296$ & & \\
\hline Muscle & 2.15 & 1.10 & $0.62-5.56$ & & \\
\hline Immature & & & & 11 & Vistula Lagoon, Poland, This study \\
\hline Liver & 10.96 & 11.42 & $1.4-40.3$ & & \\
\hline Kidney & 17.6 & 22.96 & $1.25-80.5$ & & \\
\hline Muscle & 1.6 & 0.82 & $0.49-3.64$ & & \\
\hline
\end{tabular}

etc. age classes; hence, the duration of their exposure to pollution will have been very different. In immature cormorants, the immune system and detoxification processes are not sufficiently developed.

Detoxification in these birds (elimination of $\mathrm{Hg}$ and other elements) takes place in their internal organs like the kidneys and liver (Boening 2000; Gray 2002; Kim et al. 1996) as well as in the feathers during molting (Braune 1987). In the case of cormorants, the molting period varies greatly, however, there is usually a partial molt from June to December (Baker 1993). Nam et al. (2005) observed that the $\mathrm{Hg}$ load decreases during molting
(June) since $\mathrm{Hg}$ is transferred to the feathers from internal tissues via the blood. In our study, the cormorants were shot in June, i.e., at the start of the molting period. Hence, the main reason for the wide variations in $\mathrm{Hg}$ content is that the cormorants were at different stages of individual development and molting. Table 2 compares the $\mathrm{Hg}$ concentrations in five species of fish analyzed in our study; the literature data refer to muscle samples. The table shows that $\mathrm{Hg}$ concentrations in the whole fish analyzed in our study are generally smaller than those in muscle tissue.

The BMF is discussed by Barwick and Maher (2003), Ciesielski et al. (2006), Guruge 
Table 2 Comparison of mean $\mathrm{Hg}$ concentrations (in micrograms per gram w.w.) in fish from different areas

\begin{tabular}{|c|c|c|c|c|}
\hline Fish species & $\mathrm{Hg}$ & Number & Localization & Reference \\
\hline \multirow[t]{3}{*}{$\begin{array}{l}\text { Herring } \\
\quad \text { (Clupea harengus) }\end{array}$} & $0.021 \pm 0.009$ (muscle) & 20 & $\begin{array}{l}\text { Gulf of Bothnia } \\
\text { Gulf of Finland } \\
\text { Baltic Sea }\end{array}$ & Perttila et al. (1982) \\
\hline & $0.086 \pm 0.028$ (muscle) & 52 & The Firth of Vistula & Falandysz et al. (2000) \\
\hline & $0.008 \pm 0.003($ whole $)$ & 15 & The Vistula Lagoon & This study \\
\hline \multirow{6}{*}{$\begin{array}{l}\text { Roach } \\
\qquad \text { (Rutilus rutilus) }\end{array}$} & 1.66 & & Mouth of the Vistula & Gajewska and Nabrzyski (1977) \\
\hline & 0.72 & & River & \\
\hline & 0.55 (muscle) & & & \\
\hline & $0.13 \pm 0.09$ (muscle) & 427 & $\begin{array}{l}\text { Upsala, Stockholm } \\
\text { Sweden }\end{array}$ & Sonesten (2001) \\
\hline & $0.058 \pm 0.034$ (muscle) & 26 & The Firth of Vistula & Falandysz et al. (2000) \\
\hline & $0.110 \pm 0.064$ (whole $)$ & 15 & The Vistula Lagoon & This study \\
\hline \multirow{3}{*}{$\begin{array}{l}\text { Tench } \\
\text { (Tinca tinca) }\end{array}$} & 0.26 (muscle) & & Nogat River & Gajewska and Nabrzyski (1977) \\
\hline & $0.032 \pm 0.013(\text { muscle })^{a}$ & 6 & $\begin{array}{l}\text { Záhlinice ecosystem } \\
\text { Czech Republic }\end{array}$ & Houserová et al. (2007) \\
\hline & $0.039 \pm 0.028($ whole $)$ & 15 & The Vistula Lagoon & This study \\
\hline \multirow{2}{*}{$\begin{array}{l}\text { European smelt } \\
\text { (Osmerus eperlanus) }\end{array}$} & $0.066 \pm 0.028$ (muscle) & 41 & The Firth of Vistula & Falandysz et al. (2000) \\
\hline & $0.029 \pm 0.008($ whole $)$ & 15 & The Vistula Lagoon & This study \\
\hline \multirow{2}{*}{$\begin{array}{l}\text { Ruffe (Gymnocephalus } \\
\text { cernuus) }\end{array}$} & $0.066 \pm 0.04$ (muscle) & 30 & The Firth of Vistula & Falandysz et al. (2000) \\
\hline & $0.016 \pm 0.006$ (whole) & 15 & The Vistula Lagoon & This study \\
\hline
\end{tabular}

${ }^{a}$ The concentrations were recalculated from d.w. to w.w.

et al. (1996), and Slotton et al. (2004). Biomagnification is defined as the transfer of a given xenobiotic compound from one organism to another, resulting in a generally higher concentration in the predator than in the prey. If $\mathrm{BMF}$ is higher than unity, then biomagnification has occurred (Gray 2002). The usual approach is to compare the whole body of organisms from the bottom of the food chain to some tissues from organisms at the top (Gray 2002). This, however, may yield misleading results, since some tissues (like kidney and liver in the case of cormorants) are expected to be richer in $\mathrm{Hg}$ than others (like muscles). As homogenization and analysis of relatively large animals may be hard or even impossible in practice, a method of calculating total $\mathrm{Hg}$ needs to be applied (see the calculation of the total $\mathrm{Hg}$ content in the whole cormorant body in the "Sampling and analytical method" section). As can be seen in Table 3, BMFs of $\mathrm{Hg}$ (relative to fish species) decreased in the following sequence: herring $>$ ruffe $>$ European smelt $>$ tench $>$ Crucian carp $>$ roach $=$ Prussian carp. This means there

Table 3 BMF for trophic relation cormorant-fish of the Vistula Lagoon food web

\begin{tabular}{|c|c|c|c|c|c|c|c|}
\hline \multirow{2}{*}{$\begin{array}{l}\text { Trophic relation } \\
\text { predator-prey }\end{array}$} & \multicolumn{7}{|c|}{ Fish species } \\
\hline & $\begin{array}{l}\text { Herring } \\
\text { (Clupea } \\
\text { harengus) }\end{array}$ & $\begin{array}{l}\text { Tench } \\
\text { (Tinca } \\
\text { tinca) }\end{array}$ & $\begin{array}{l}\text { Roach } \\
\text { (Rutilus } \\
\text { rutilus) }\end{array}$ & $\begin{array}{l}\text { European } \\
\text { smelt } \\
\text { (Osmerus } \\
\text { eperlanus) }\end{array}$ & $\begin{array}{l}\text { Ruffe } \\
\text { (Gymnocephalus } \\
\text { cernuus) }\end{array}$ & $\begin{array}{l}\text { Crucian carp } \\
\text { (Carassius } \\
\text { carassius) }\end{array}$ & $\begin{array}{l}\text { Prussian carp } \\
\text { (Carassius } \\
\text { gibelio) }\end{array}$ \\
\hline Cormorant (muscle)-fish & 80 & 15 & 5 & 20 & 40 & 10 & 5 \\
\hline Cormorant (kidney)-fish & 870 & 170 & 60 & 222 & 420 & 140 & 60 \\
\hline Cormorant (liver)-fish & 580 & 110 & 40 & 150 & 280 & 90 & 40 \\
\hline Cormorant (feathers)-fish & 1,040 & 200 & 71 & 270 & 50 & 160 & 70 \\
\hline Cormorant (whole body)-fish & 160 & 30 & 10 & 40 & 80 & 25 & 10 \\
\hline
\end{tabular}


is considerable biomagnification of $\mathrm{Hg}$ in the cormorant relative to its fish prey, especially in the cormorant-herring trophic relationship. It should be emphasized that biomagnification in the study area was well reflected by the high BMF for the cormorant-ruffe trophic relation (the ruffe is a major item in the cormorant diet) and to a lesser extent by the cormorant-roach and cormorantPrussian carp relations (the Prussian carp is not a common prey).

\section{Conclusions}

It was found that $\mathrm{Hg}$ concentrations were greater in kidney, liver, and feathers. The BMF estimated for $\mathrm{Hg}$ relative to diffrent fish species was significantly greater than unity, especially for the cormorant-herring trophic relationship. This means that there is biomagnification of $\mathrm{Hg}$ in cormorants relative to their prey. The data obtained are helpful for a better understanding of the accumulation processes of $\mathrm{Hg}$ in selected tissues of cormorants in the Vistula Lagoon ecosystem.

Acknowledgements The authors gratefully acknowledge the financial support received from grant no. N305 049336 of the Polish Ministry of Science and Higher Education. We are indebted to Dr. Gerard Kanarek who assisted with collecting the biological material.

Open Access This article is distributed under the terms of the Creative Commons Attribution Noncommercial License which permits any noncommercial use, distribution, and reproduction in any medium, provided the original author(s) and source are credited.

\section{References}

Baker, K. (1993). Identification guide to European nonpasserines, guide 24. Thetford: British Trust for Ornithology.

Barwick, M., \& Maher, W. (2003). Biotransference and biomagnifications of selenium, cadmium, zinc, arsenic and lead in a temperate seagrass ecosystem from Lake Macquarie Estuary, NSW, Australia. Marine Environmental Research, 56, 471-502.

Boening, D. W. (2000). Ecological effects, transport, and fate of mercury: A general review. Chemosphere, 40, 1335-1351.

Braune, B. M. (1987). Comparison of total mercury levels in relation to diet and molt for nine species of marine birds. Archives of Environmental Contamination and Toxicology, 16, 217-224.

Brylińska, M. (1991). Ryby stodkowodne Polski. Warszawa: PWN.

Burger, J., \& Gochfeld, M. (2001). Metal levels in feathers of cormorants, flamingos and gulls from the coast of Namibia in Southern Africa. Environmental Monitoring and Assessment, 69, 195-203.

Bzoma, S., Goc, M., Brylski, T., Stempniewicz, L., \& Iliszko, L. (2003). Seasonal changes and intra-colony differentiation in the exploitation of two feeding groups by Great Cormorants Phalacrocorax carbo sinensis breeding at Katy Rybackie. Vogelwelt, 124, $175-181$.

Caldwell, C. A., Arnold, M. A., \& Gould, W. R. (1999). Mercury distribution in blood, tissues, and feathers of double-crested cormorant nestlings from arid-lands reservoirs in south central New Mexico. Archives of Environmental Contamination and Toxicology, 36, 456-461.

Ciesielski, T., Pastukhov, M. V., Fodor, P., Bertenyi, Z., Namiśnik, J., \& Szefer, P. (2006). Relationships and bioaccumulation of chemical elements in the Baikal seal (Phoca sibirica). Environmental Pollution, 139, 372-384.

Ezhova, E., Żmudzinski, L., \& Maciejewska, K. (2005). Long-term trends in the macrozoobenthos of the Vistula Lagoon, southeastern Baltic Sea. Species composition and biomass distribution. Bulletin of the Sea Fisheries Institute, 164, 55-73.

Falandysz, J., Chwir, A., \& Wyrzykowska, B. (2000). Total mercury contamination of some fish species in the Firth of Vistula and the Lower Vistula River, Poland. Polish Journal of Environmental Studies, 9(4), 335339.

Gajewska, R., \& Nabrzyski, M. (1977). Zawartość rtęci, kadmu i ołowiu w rybach morskich i słodkowodnych. Roczniki Państwowego Zakładu Higieny, 28(2), 215224 (In Polish with English summary).

Goc, M. (2004). Phalacrocorax carbo (L., 1758)kormoran. In M. Gromadzki (Ed.), Ptaki (part I). Poradnik ochrony siedlisk i gatunków Natura 2000podrecznik metodyczny (Vol. 7, pp. 53-57). Warszawa: Ministerstwo Ochrony Środowiska.

Goc, M., Iliszko, L., Brylski, T., Chełkowska, N., \& Filcek, J. (2003). Daily, seasonal and interseasonal variation in the timing of foraging flights at the Great Cormorants Phalacrocorax carbo sinensis colony at Katy Rybackie (N Poland). Vogelwelt, 124, 197-203.

Gray, J. S. (2002). Biomagnification in marine systems: The perspective of an ecologist. Marine Pollution Bulletin, $45,46-52$.

Guruge, K. S., Tanabe, S., Iwata, H., Tatsukawa, R., \& Yamagishi, S. (1996). Distribution, biomagnification, and elimination of butyltin compound residues in common cormorants (Phalacrocorax carbo) from Lake Biwa, Japan. Archives of Environmental Contamination and Toxicology, 31, 210-217.

Henny, C. J., Hill, E. F., Hoffman, D. J., Spalding, M. G., \& Grove, R. A. (2002). Nineteenth century mercury: 
Hazard to wading birds and cormorants of the Carson River, Nevada. Ecotoxicology, 11, 213-231.

Honda, K., Marcovecchio, J. E., Kan, S., Tatsukawa, R., \& Ogi, H. (1990). Metal concentration in pelagic seabirds from the North Pacific Ocean. Archives of Environmental Contamination and Toxicology, 19, 704-711.

Houserová, P., Hedbavny, J., Matejcek, D., Kracmar, S., Sitko, J., \& Kuban, V. (2005). Determination of total mercury in muscle, intestines, liver and kidney tissues of cormorant (Phalacrocorax carbo), great crested grebe (Podiceps cristatus) and Eurasian buzzard (Buteo buteo). Veterinary Medicine-Czech, 50(2), 61-68.

Houserová, P., Kubáň, V., Komar, S., \& Sitko, J. (2007). Total mercury and mercury species in birds and fish in an aquatic ecosystem in the Czech Republic. Environmental Pollution, 145, 185-194.

Kanarek, G., \& Rolbiecki, L. (2006). Third-stage larvae of Anisakis simplex (Rudolphi 1809) in the Great Cormorant [Phalacrocorax carbo sinensis (Blumenbach, 1798)] from the Vistula Lagoon, Poland. Oceanological and Hydrobiological Studies, 35, 23-28.

Kim, E.-Y., Saeki, K., Tanabe, S., Tanaka, H., \& Tatsukawa, R. (1996). Specific accumulation of mercury and selenium in seabirds. Environmental Pollution, 94(3), 261-265.

Martyniak, A., Wziątek, B., Szymańska, U., Hliwa, P., \& Terlecki, J. (2003). Diet composition of Great Cormorants Phalacrocorax carbo sinensis at Katy Rybackie, NE Poland, as assessed by pellets and regurgitated prey. Vogelwelt, 124, 217-225.

Nam, D. H., Anan, Y., Ikemoto, T., Okabe, Y., Kim, E.-Y., Subramanian, A., et al. (2005). Specific accumulation of 20 trace elements in Great Cormorants (Phalacrocorax carbo) from Japan. Environmental Pollution, 134, 503-514.

Perttila, M., Tervo, V., \& Parmanne, R. (1982). Heavy metals in Baltic herring and cod. Marine Pollution Bulletin, 13(11), 391-393.

Przybysz, J. (1997). Kormoran. Monografie przyrodnicze. Świebodzin: Wydawnictwo Lubelskiego Klubu Przyrodników.
Psuty, I. (2010). Natural, social, economical and political influences on fisheries: A review of transitional area of the Polish waters of the Vistula Lagoon. Marine Pollution Bulletin, 61, 162-177.

Saeki, K., Okabe, Y., Kim, E.-Y., Tanabe, S., Fukuda, M., \& Tatsukawa, R. (2000). Mercury and cadmium in common cormorants (Phalacrocorax carbo). Environmental Pollution, 108, 249-255.

Scheuchammer, A. M., \& Graham, J. E. (1999). The bioaccumulation of mercury in aquatic organisms from two similar lakes with differing $\mathrm{pH}$. Ecotoxicology, 8, 49-56.

Slotton, D. G., Ayers, S. M., Suchanek, T. H., Weyand, R. D., \& Liston, A. M. (2004). Mercury bioaccumulation and trophic transfer in the Cache Creek Watershed of California, in relation to diverse aqueous mercury exposure conditions. Assessment of ecological and human health impacts of mercury in the San Francisco Bay-Delta Watershed. Final Report.

Sonesten, L. (2001). Mercury content in roach (Rutilus rutilus L.) in circumneutral lakes-effects of catchment area and water chemistry. Environmental Pollution, 112, 471-481.

Stempniewicz, L., \& Grochowski, A. (1997). Diet composition of cormorants in the breeding colony of Katy Rybackie, NE Poland (regurgitated preys, 1992-94). Supplemento alle Ricerche di Biologia della Selvaggina, 26, 537-544.

Stempniewicz, L., Martyniak, A., Borowski, W., \& Goc, M. (2003). Interrelationships between Ruffe Gymnocephalus cernuus and Great Cormorants Phalacrocorax carbo sinensis in the Vistula Lagoon, N Poland. Vogelwelt, 124, 261-269.

Szefer, P. (2002). Metals, metalloids and radionuclides in the Baltic Sea ecosystem. Amsterdam: Elsevier Science B.V.

Uścinowicz, S., \& Zachowicz, J. (1996). Geochemical atlas of the Vistula Lagoon 1: 150 000. Warszawa: Polish Geological Institute (In Polish).

Wang, Q., Kim, D., Dionysiou, D. D., Sorial, G. A., \& Timberlake, D. (2004). Sources and remediation for mercury contamination in aquatic systems-a literature review. Environmental Pollution, 131, 323-336. 